\title{
Adolescents and Facebook: Narcissus without (an) echo*1
}

Laetitia Petit*2

Anne Boisseuil*3

Sandie Iffli*4

After discussing the reasons for Facebook's popularity among adolescents, we proceed by analyzing the different types of superego and their structure during the great psychic upheaval of this developmental period. The prevalent use of the logic of orality and anality by Facebook causes regression in adolescents and may provoke a de-eroticization or even a desexualization of the Oedipal superego. This puts the cultural and the archaic superegos to the forefront, which may ultimately result in complete avoidance of sexuality, as it is experienced as dangerous. All of these factors may threaten the structuring capacity of the categories of lack and desire.

Key words: Facebook, cultural superego, device, de-eroticization, adolescence

*1 Translated by John Holland.

*2,3,4 Aix-Marseille University (Aix-Marseille, France). 


\section{Narcissus without (an) echo: Images without a voice}

We propose to examine the Facebook apparatus as an adolescent activity, focusing especially on the apparatus itself, as Giorgio Agamben (2009) understands this term, ${ }^{1}$ and particularly in reference to his discussion of Jean Hyppolite and Michel Foucault's dialogue on Hegel. To these propositions, we would like to add the crucial problematic of infantile sexuality, which brings with it the always complex and contradictory movement of the unconscious (...) Although Facebook is involved with many other social networks, one could easily think that it possesses a specificity when compared to others such as Twitter, as regards both its history and it aims. We think of the Facebook apparatus as a very welldeveloped form of an illustrated diary which allows for action on both time and space. We propose to examine the singularity of its interactive virtual dimension, while restricting the discussion to adolescence. We suppose the reader is familiar with Facebook and its history. ${ }^{2}$ Here we will be taking a critical look at the effects of the site, while acknowledging the work of other authors who have explored the significant role Facebook can have in shoring up the adolescent's experience. We do not intend to vilify the site, however, for each person is responsible for the way in which he or she uses it. Current literature on Facebook reveals that the site is, quite indisputably, one of the alternatives to which adolescents have recourse when they are

${ }^{1}$ Agamben defines an apparatus as follows:

To generalize further the already expansive class of Foucauldian apparatuses, I shall call an apparatus literally anything that has in some way the capacity to capture, orient, determine, intercept, model, control, or secure the gestures, behaviors, opinion, or discourses of living beings. Not only, therefore, prisons, madhouses, the panopticon, schools, the confessional, factories, disciplines, juridical measures, and so forth (whose connection with power is in a certain sense evident), but also the pen, writing, literature, philosophy, agriculture, cigarettes, web browsing, computers, cellular telephones and - why not - language itself, which is perhaps the most ancient of apparatuses - one in which thousands and thousands of years ago a primate inadvertently let himself be captured, probably without realizing the consequences that he was about to face (2009, p. 14).

${ }^{2}$ For a discussion of the history of Facebook, see (Borel, 2012) and (Fincher, 2010). 


\section{ARTIGO}

dealing with the constraints on the drives and the upheaval that characterize this developmental period. For example, by translating the English term "breakdown" into French as "panne," a term referring to mechanical failures, Rassial (1996) highlights the subtlety of the adolescent Moses Laufer's psychical efforts, which consist in his capacity to transform his experience of breakdown or depression in response to the deceptive nature of the Oedipal promise - "you can, but later on" - into unprecedented cathexes determined by genitality. Such a transformation implies a series of operations which, when traversed successfully, gives the adolescent the chance "(...) not to have to be a "normally' neurotic adult" (p. 208).

We will begin with a brief description of the apparatus, then we will examine different figures of the superego insofar as the latter determines the modes whereby objects are cathected, as regards not only repression and sexuality, but also the ways the superego is constituted and its effects. Lastly, we will describe the entanglements of pregenital and Oedipal sensorimotor dynamics as an effect of Facebook, another element that will extend and support our thesis.

There are many lines of inquiry here, for Facebook calls for a kind of psychic work not only as a consequence of its "group" quality but also through its narrative character. ${ }^{3}$

One frequently hears it said that Facebook takes part in reproducing something that we could think of as a second experience of the mirror stage, except, we would add - and this is a rather important difference - here the mother is replaced by the community of friends and by anonymous moderators. Facebook is a concrete application of a new kind of power that is characterized by the absence of an identifiable agent; it "infiltrates the subject itself by all manner of inducements, seductions, and orders, in the mode of an undetectable and silent omnipotence" (Lebrun \& Gastambide, 2013, p. 207). Yet anyone can "block" the visible element, that exposed part of the subject. Censorship occurs anonymously, for any friend can block images. The place and the role of the leader remain undefined, for manifestations of "leadership" are unpredictable and depend on the constitution of the apparatus itself which develops in time, both from a technical point of view and in terms of the expressive framework that it provides. Furthermore, it is not hard to imagine that spiraling into insult is both possible and uncontrollable. At the heart of the apparatus is a constraining ideal, which is accompanied by a logic of binary expressions - Like/Unlike, ignore, block, delete, remove from list of friends, report - and the expression

${ }^{3}$ Much excellent work has already been done on these issues. For example, see (Auvray \& Fuchs, 2007; Vinocur Fischbein, 2010; Friedman, 2005; Potier, 2009; Tisseron, 2007). 
of ideals such as "lovely" and "like." This ideal turns Facebook into a tool that both authorizes and regulates conformism. Its beautiful surface opens up, in equal measure, a corollary that consists of negative statements: no racism, no sex; these are manifestations of the superego and its censorship function.

We are thus talking about a false freedom: the rule of censorship is arbitrary. In the narrative as well as through the image, we can see that the space for transgression is minimal, which adds to the conformist character of the apparatus itself and its users.

Since the cultural superego is entirely directed towards symbolization and the substitutive formations stemming from repression, its de-eroticizing, and even desexualizing character must be recognized. Thus, although Facebook can be used in the context of adolescent operations ${ }^{4}$ both to promote identification with the other sex through a community of peers and to reduce the trauma related to the emergence of sexuality, it can also have other effects. It can encourage the construction of a cultural superego pushed to its extreme consequences, and can thereby bring about a disentwining of the drives. Facebook then becomes an apparatus for evading the sexual, by submitting to the desexualizing character of the cultural superego.

Next we will seek to conceptualize the way in which the apparatus of 666 Facebook serves the desexualizing and de-eroticizing aspects of the superego.

\section{Which Superego?}

In 1929, Freud presented a conception of the cultural superego as a continuation of the Oedipal superego In Civilization and Its Discontents, he highlights the analogy between the cultural process and the path of the individual's development: "At this point we cannot fail to be struck by the similarity between the process of civilization and the libidinal developments of the individual" (1929/1961, p. 97). Culture aims “(...) to protect men against nature and to adjust their mutual relations," and the cultural superego seeks to further the ideals of humanization by preserving the subject from helplessness and aggression; it is thereby accompanied by a reinforcing of the desexualization of the Oedipal superego (1929/1961, p. 89). Culture concerns “(...) the whole sum of the achievements and regulations which distinguish our lives from those of our animal

\footnotetext{
${ }^{4}$ The use of the term "adolescent operations" to describe adolescent processes was suggested by Jean-Jacques Rassial (2000).
} 


\section{ARTIGO}

ancestors (...)" (1929/1961, p. 89). By insisting on its desexualized character that is, on the refusing, ${ }^{5}$ the renunciation of the drives, which presupposes the non-satisfaction, the repression of powerful drives - Freud makes the superegoof-civilization into an instance that unifies several different kinds of superego. In Civilization and Its Discontents, in the context of his discussion of that first anxiety which occurs when one is faced with primordial authority, Freud implies that there is an archaic superego, although he does not use this term. For Melanie Klein, the archaic superego precedes the Oedipal organization and refers to a partial object. It is a fierce and archaic figure formed from the imagos of the breast. The prototypical drive dynamic involves a devouring sensory object, the eye-mouth. The good and the bad must then be split in order to protect the good object from envious attacks. Klein sketches out the characteristics of this archaic, tyrannical, cruel and vengeful superego, through its link with the oral stage (the paranoidschizoid phase). The extreme severity of the superego in the sadistic oral phase is connected especially with biting, which is characteristic of the second oral sub-stage, which she takes from Karl Abraham (1979). The object's response, which is made in a "detoxified" manner, allows for the reduction of persecutory anxiety and a progressive tolerance for the desire for the object (Bion, 1967). Here we again find the transformation of the psychic organization into an "all or nothing," which is characteristic of the primal mental functions that are reactivated in adolescence.

Following Freud and Klein, Jacques Lacan (1957-1958/1998) defines the superego as that on which the laws of speech are based. ${ }^{6}$ It is bound to the founding speech of the symbolic mother, in opposition to immediate satisfaction of the drive. The Oedipal superego is distinguished from the first by the fact that in this instance, the founding "discourse" comes from the father, who both prohibits and opens up the possibility of genital sexuality.

To this, Bernard Penot adds that "paternal" discourse works because, in practice, it "tops off" the register of the big omnipotent maternal Other; it marks out its contours, thereby working to set structuring limits (1995, p. 85).

${ }^{5}$ We would like to thank Marie Lenormand and Nicolas Guérin for bringing to our attention that Versagung can best be translated as "refusing" [refusement], as proposed in Traduire Freud (Bourguignon, Cotet, Laplanche, \& Robert, 1989). [Translator's note: In the Standard Edition of the Works of Sigmund Freud, "Versagung" is translated as "frustration" (Laplanche \& Pontalis, 1974, pp. 175-176).]

${ }^{6}$ See Lacan's (1998) construction of the graph of desire and the laws of speech.

${ }^{7}$ It would be more accurate to speak of the father's voice rather than the father's "discourse," except to distinguish between the father and the discourse of the master. 
We thus see that the absence of this discourse (on which symbolic castration is based) leads to a resurgence of archaic superego commandments saturated with narcissistic sufficiency, which are the source of the disavowal of reality; such a situation allows a superego with the imaginary consistency of a voice to emerge: the "harsh voice".

In the end, the discourse that founds the cultural superego is that of the Master ${ }^{8}$ : the discourse of the father insofar as it exceeds the Oedipus complex and is the basis of the humanizing social bond. This cultural superego is necessary because of the lack of a sexual relation, and one of the logical implications of the Oedipus complex is the discovery that the promise of genital sexuality is misleading. In retaining the repressive character of the cultural superego but extending Freud's conclusions, Lacan defines the cultural superego as discontinuous with the Oedipal superego, for it gets rid of the aspect of the Oedipal superego (and every ego ideal) that promises sexuality; the Oedipal superego is sacrificed for the benefit of the cultural superego, which itself promises only some "ideals of nothingness" (Lacan, 1951/2006, p. 112).

If, as we have shown, the Facebook apparatus reduces the cultural superego to the archaic superego, to the detriment of the Oedipal superego, we can see that the "discourse" - or rather, the voice - of the father disappears, leaving only 668 those of the mother and of the discourse of the Master (i.e., the discourse of the father insofar as he is the founder of the social bond) who in fact does not have a voice. ${ }^{9}$

In other words, all conflict disappears and even the calming of the conflict itself can represent a hindering of the operations that permit the process and traveral of adolescence.

By saving the promise of the Oedipal superego, one reactivates, on the contrary, the promising path of conflict stemming from the discontinuity between the Oedipal superego and the cultural superego, a path that can then be elaborated. The adolescent, more than anyone else, suffers from this disparity, in particular as regards the conflict between the father of his or her actual family, who upholds the symbolic function (if you renounce maternal jouissance, you will gain access to genitality) and the function of the father that surpasses the Oedipal and is

${ }^{8}$ Here is Rassial's (1996) definition of this discourse:

In my approach, the "discourse of the master" is the discourse that founds both the social bond and the subject's existence in language [langue]; it does so by imposing its master signifiers, which have the virtual value of Names-of-the-Father, at the price of the repression of desire, which it represents in the social arena. (p. 51)

${ }^{9}$ That is, it only has a disembodied voice that does not enable psychic integration. 


\section{ARTIGO}

the basis of the social bond. It will not come as a great surprise that it is precisely during adolescence that this conflict between the two superegos is expressed most concretely, to the point that Rassial has shown the possibility of an unfavorable solution: the splitting of the superego in adolescence. The adolescent fumbles about, shaken up and unbalanced by two founding statements: the speech of the actual father - who upholds the symbolic function - and the discourse of the father on whom the social bond is based. As Rassial (1996) states:

Socialization is only possible on the condition that the continuity between the discourse-of-the-father [that is, the father of the family who upholds the symbolic function] and the discourse-of-the-master [the discourse of the father insofar as it exceeds the Oedipal, and on which the social bond is based] is concealed, or even erased, so that the latter is gently substituted for the former, thus seeming to preserve the protective attributes of the parental superego. (p. 55)

We can show how the ideal that this apparatus proposes can fail: although it offers a comforting shoring up of the adolescent, who is faced with the horror of the sexual encounter, it nevertheless does not allow any alternative to this sexual encounter. It thus serves to produce a de-eroticized sexuality. The apparatus demonstrates how the cultural superego can be reduced to the archaic superego, against the Oedipal superego. The term "against" as used here should be understood as a factor that would obstruct the very existence of the other. However, it also has spatial connotations: right beside, very close, even too close. What is lacking is the intermediate space that allows for conflict (and perhaps for narrative, as well?).

The Facebook Wall becomes a surface for self-exhibition involving even the most trivial of one's activities and thoughts. It becomes a sort of "extimacy" (Tisseron, 2001) against the borders of intimacy, on which a community can be built. This creation of an "extimate" (Lacan, 1957-1958/1998) participates in a refusal of the neurotic splitting between public and private, which used to function as a structuring delimitation. The refusal must take a positive form: it needs to involve a choice, a taking of position that conditions the operations of the adolescent. As such, it becomes easy to understand the success of this magnificent basis for externalization. However, this promising approach to psychic operations does not seem to work as well as it might, for it is something that is imposed on the unwitting adolescent, rather than chosen and accepted as a responsibility. The adolescent sees him- or herself as subjected without limit to the discourse of the Other in the form of the apparatus (....) Here, such extimacy is the result of the effect of the apparatus and not of a choice on the part of the subject for which he or she would bear responsibility. 


\section{Regressions to Archaic Forms of Narcissism, Group Illusions ${ }^{10}$ and Immersion in Primary Processes}

In the Facebook apparatus, pregenital drives find a thoroughly fertile ground: the value attributed to the number of friends becomes more important than the quality of the bond with the other, in a logic of the oral, whereas mastery over the acceptance or rejection of these friends (or the illusion thereof) evokes a logic of the anal.

The inflation of the number of friends can be called "voracious" because this number will always be insufficient. Thus, Facebook "friends" are often just "extras"; real conversations occur only with a select few. That might well correspond to how things are in the "real world," where it is common to have many more acquaintances than friends, but in this context the word "friends" really loses its symbolic depth. "Friend" no longer designates a bond of affection, but instead, a function of the address book. For a person in crisis, who rediscovers his or her bonds in the symbolic sense, the ease by which Facebook allows for the loss of what is significant can prove to be a catalyst for pathology; this can occur because of the confusion between the imaginary and the symbolic, which has been located earlier, and which can lead to the invasion of the imaginary. Both writing in the third person and the possibility of commenting anonymously bring about a sense of distance, and even of avoidance of oneself; the subject thus becomes a pre-symbolic figure utterly devoid of personality. Anonymity is made possible by the use of pseudonyms that also permit the subject to change its sex. This brings in the issue of gender.

Avoiding oneself in this way can also be observed on the level of time, since posted texts and photos can be "reposted." This removes the temporal dimension - the past can become the present and vice versa - something that corresponds closely (sometimes too closely) to the absence of logical linearity in unconscious temporality. We draw attention to this potentially creative aspect because it brings up the issue of how direct satisfaction of the pleasure principle organizes the dynamic.

As a result not only of the group aspect of the apparatus but also the virtual quality of this imaginary, which acts as if it is real, we observe a generalized confusion of limits and a porousness of spaces, as well as the resurgence of a subjectivity dominated by the primary processes (splitting, projection); these are responses to the sensory dissociation between eye and voice that Facebook imposes.

${ }^{10}$ This is a reference to Didier Anzieu's (1984) book The Group and the Unconscious. 


\section{ARTIGO}

In Facebook, the visual and the sensorimotor are in the ascendant, since typing texts and moving a mouse require bodily movement; thus emotional impact is immediate, as is the correlative sense of intrusion and persecution. Here again, we encounter the idea of the archaic superego, which engenders tyrannical and intensely persecutive experiences precisely because it is not organized around a clear distinction between self and other.

\section{Avoidance of castration}

Klein situates the sadistic-oral stage within the schizo-paranoid phase, during which the baby oscillates between processes of introjection and projection and feelings of disintegration and persecution; the aim of this movement is integration and the construction of the ego. Because the concept of otherness has not been fully developed, the baby rejects the bad qualities in itself and shifts them onto the other. Guignard (1996) describes the phase of intolerance of frustration as a violent hatred of reality, a hatred that provokes the destruction of connections and functions that would have made contact with this reality possible. Thus, a preference for the virtual signals a refusal to face frustration. Gutton (1991) suggests that one can exit from the primal and enter into the primary by tolerating the other's presence as a mirror. Now, this supposes a sensory reality that is negligible in the virtual environment of the computer program.

We will not re-examine Facebook's apparently non-conflictual character, defined by the sole criterion of "Like," but it is also possible, with nothing but a click, to stop liking something. This is an extreme form of the return of the repressed. This space of group activity does not allow for any response to hatred other than through the negative form of discharge, or evacuation of the affect; this is a sign of the degree of violence potentially contained within the Facebook apparatus. How, indeed, can one gain access to these voices that speak from limbo? This calls for starting from the negative....

\section{The disavowal of the oedipal superego}

In this glimmering space, the subject seems thus to revisit archaic forms of narcissism. The possibility of exercising mastery over time and space is 
assimilated with omnipotence, including infantile omnipotence, which Gozlan (2012) calls gratuitous action ${ }^{11}$ on the world. In other words, acting without paying the price of castration. This abolishes all temporal and spatial censorship. Eyes become, in the words of Louis-Vincent Thomas, "carnivorous" (1988, pp. 10-11). This ocular cannibalism is evidence of oral regression. The question of desire can be evaded by avoiding lack.

Infantile omnipotence is found to some extent in Facebook. One expression of this submission is a new trend in which, for example, people post photographs of their meals. When "your stomach is a big as your eyes," limits are blurred. The fantasmatic organization involves a cannibalistic relation between opposing terms: an object to be devoured, incorporated can metamorphose just as quickly into a devouring object. In expecting a series of "symbol-generating castrations" [castrations symboligènes] (Dolto, 1984), we find, on the contrary, an excess of regressions that call upon orality and anality, in the sense of a pregenital that prevents the genital.

It involves a regression in group experience, which includes therapeutic effects familiar to us from the analysis of group illusions and the adjustments such experience brings about. These are preserved from the sort of organization that is based on discourse. The mother's voice is what is heard in the experience of mirroring; the father's voice acts to deprive the child of this. We thus see how the lack of a voice in the Facebook apparatus produces some ambiguity concerning the organization of the drives, to say the least. Because it concerns foundational speech, we thus might see an opposition between speech without discourse (Father, Mother, Other) and discourse without speech (the discourse of the father insofar as it exceeds the Oedipal, insofar as it establishes the social bond), or the discourse of the master.

Penot (1995) sets up a contrast between "true" speech, which presupposes a desiring subject, and the verbal expression (not necessarily spoken aloud) "(...) of the imperatives of narcissistic conformity," which are subjugated to orders that he qualifies as "superego-esque" (p. 71).

Activation of the organizing psychic processes seems to be prevented, or slowed down, rather than stimulated by the leveraged element of the apparatus. As concerns the voice, two types of practices can be observed. There is the emotional "lever" that the apparatus favors, for example by "posting" some music that

${ }^{11}$ [Translator's note: The French term used here, "à l'œil," means "for free" or "gratis," in the sense of an unlimited or "all you can eat" buffet (literally, "you can eat all of what you see"). In the present context, we might also think of the expression, "the master of all he surveys."] 


\section{ARTIGO}

expresses one's current mood on the Facebook wall, as if that involved a sort of search for an ultimate signifier that could disrupt all the others. Then there is the "brake" quality of the apparatus in its conflict-avoidance function: highlighting a song enables one to avoid expressing thoughts and feelings. Song lyrics thus become a pretext for insults and criticisms. The user has recourse to another "language," whether that of music, a foreign language or Facebook's own code. Because it provides a sensory container for an overflow or a bursting or sensations, this process should be understood as involving both a lever and a brake.

\section{Evacuation of the Voice}

With the addition of Skype, the visual and the vocal can now become intertwined. In reference to Winnicott's theory of mirroring, one could say that if Skype is less narcissistic in nature and implies an Oedipal dimension, then introducing sound into the Facebook interface would be a sign of the transformation of a narcissistic relation with the object into a triangular relation. As a result, the sensory quality is located in different places in these two aspects of the apparatus. In the first case, it is split and binary, in a way that corresponds to primary processes of subjectification; in the second case, its transformation by the coupling of voice and eye places it within the secondary process. It should be noted that the wealth of meaning of this proposition has not been drawn out, as if it were somehow in contradiction with the very logic of the Facebook apparatus itself. Taking leave of the Winnicottian frame with a specular conception of the mother's real voice, we return to Lacan, for whom the voice in the mirror-stage experience is first and foremost the basis of naming. It is not really possible to connect this with the use of Facebook because, as we have shown, the image, along with the voice conceived as an agency of naming, are watered down.

We have wondered to what extent the evacuation of the voice would lead to a reinforcement of the collective superego, in the same way that, as Freud (1929/ suggests, the human being's adoption of an erect posture cleared the way for culture, through the repression of both anal eroticism and the smell of excreta: the upright stance produces a distance between the sexual organs and the anus (1961, pp. 99-100, note 1). Here is it a matter of a disentwining of the drives, pushed to the extreme.

When the voice is not used for shouting or crying out, it is supported by naming and by speech. It thus opens the door to the language within which the subject manifests its desire by speaking. The voice is that which carries the desire of the subject in speech; this is a law of subjectification. Evacuation of the 
voice means making room for silence, a lawless silence that transmits jouissance because it is permeated by an ever more voracious and insatiable death drive, which cuts all the connections with reality.

We can see how the use (or even the politics) of this apparatus leads to a de-eroticization of the sexual encounter for adolescents, precisely because it involves the avoidance of the question of desire. The object would be totally satisfying, a characteristic that can only be envisioned in a primal space, which disavows the lack that is inevitably produced by the very act of speaking about desire. This example of sonorous evacuation in the apparatus enables us to note the limited extent to which it permits the integration of sound. If Facebook is an apparatus characterized by a narcissistic cathexis, what sort of drive organization would this process of regression bring about?

What the hysteric exacts [revendication] becomes itself a vindication. Facebook users do not formulate a demand and the object becomes a right. They address themselves to the Master and the object becomes a commodity that reigns as Master. Perhaps it would be more accurate to conceive of this apparatus as a fetishized object located in the place of the agent, a conception that would take the capitalist discourse as its corollary. It would be interesting, of course, to see whether this apparatus has specifically sexual uses and the proposals of new networks, such as Pinterest, for example, would tend to indicate that this is the case (Noan \& Cerdeira, 2012). To conclude, further work on online "adult" dating and "sex hookup" sites would strengthen this observation that there is an imperative to conform and a reification of the sexual encounter, whether these sites are used by older adolescents or by adults.

This is precisely why we must address our criticism of social networking sites such as Facebook not to the apparatus itself but instead to the ways in which it is used. We do not fully agree with Agamben's categorical position when he warns against the "(...) vanity of the well-meaning discourse on technology (...)" (2009, p. 21). He does discuss the "counter-apparatus" of "profanation," which would restore to the profane sphere the apparatuses with which we are involved in the "current phase of capitalism"; current apparatuses "(...) no longer act as much through the production of a subject, as through the processes of what can be called desubjectification" (2009, p. 19, 21). We believe we have shown, on the contrary, that the only worthwhile profanation comes from within the apparatus itself: by using it, one can have the concrete and immediate possibility of turning a constraint into its opposite. This nuance, however, does not render criticism of the apparatus invalid. 


\section{ARTIGO}

\section{References}

Abraham, K. (1979). A Short Study of the Development of the Libido. In Selected papers of Karl Abraham, M.D (pp. 422-433). New York: Brunner/Mazel.

Agamben, G. (2009). “What Is an Apparatus?” and Other Essays. (D. Kishik \& S. Pedatella, Trans.). Stanford: Stanford University Press.

Anzieu, D. (1984). The Group and the Unconscious. (B. Kilborne, Trans.). London, Boston: Routledge \& Kegan Paul.

Auvray, M., \& Fuchs, P. (2007). Perception, immersion et interactions sensorimotrices en environnement virtuel. Intellectica, (45), 23-35.

Bion, W. R. (1967). Second Thoughts: Selected Papers on Psycho-Analysis. London: W. Heinemann.

Borel, S. (2012). Facebook, stade suprême de la quête de reconnaissance. Revue du MAUSS, (2), 257-266.

Bourguignon, A., Cotet, P., Laplanche, J., \& Robert, F. (1989). Traduire Freud. Paris: Presses Universitaires de France.

Dolto, F. (1984). L'image inconsciente du corps. Paris: Éditions du Seuil.

Fincher, D. (2010). The Social Network [Motion picture]. USA: Columbia Pictures.

Freud, S. (1961). Civilization and Its Discontents. In The Standard Edition of the Complete Psychological Works of Sigmund Freud. (J. Strachey, trans., Vol. XXI, pp. 57-146). London: Hogarth Press.

Friedman, L. (2005). Flirting with virtual reality. The Psychoanalytic Quarterly, 74(3), 639-660.

Gozlan, A. (2012). Le théâtre de Facebook: réflexion sur l'usage des images chez les adolescents. Presented at the Pandora Conference "Corps et Arts - Images de l'hystérie au XXIème siècle," Vienna.

Guignard, F. (1996). Au vif de l'infantile: reflexions sur la situation analytique. Lausanne: Delachaux et Niestlé.

Gutton, P. (1991). Le pubertaire [The pubescent]. Paris: Presses Universitaires de France.

Lacan, J. (1998). Le séminaire. Livre V. Les formations de l'inconscient. (J.-A. Miller, Ed.). Paris: Éditions du Seuil. (Original work published in 1957-1958).

Lacan, J. (2006). A Theoretical Introduction to the Functions of Psychoanalysis in Criminology. In Écrits: The First Complete Edition in English (B. Fink, trans., pp. 102-122). New York: W.W. Norton \& Co. (Original work published in 1951).

Laplanche, J., \& Pontalis, J. B. (1974). The Language of Psycho-analysis. (D. Nicholson-Smith, Trans.). New York: W.W. Norton \& Co.

Lebrun, J., \& Gastambide, M. (2013). Oreste, face cachée d'Oedipe? Actualité du matricide. Ramonville Saint-Agne: Éditions érès. 
Noan, P. L., \& Cerdeira, A.-S. (2012, January 19). Pinterest: mieux que le reste? Retrieved from http://ecs-paris.com/blogs/digicom-2012/reseaux-sociaux/pinterest-mieux-quele-reste

Penot, B. (1995). L'instance du Surmoi dans les Ecrits de J. Lacan. In Monographies de psychanalyse de la revue française de psychanalyse (Vol. 58, pp. 69-94). Paris: Presses universitaires de France.

Potier, R. (2009). Au risque du Virtuel? Topique, 107(2), 149-162. doi:10.3917/ top. 107.0149

Rassial, J.-J. (1996). L'adolescent et le psychanalyste. Paris: Payot \& Rivages.

Rassial, J.-J. (2000). Un clivage du surmoi? In Le passage adolescent: de la famille au lien social. Ramonville Saint-Agne: Éditions érès.

Thomas, L.-V. (1988). Anthropologie des obsessions. Paris: Éditions l'Harmattan.

Tisseron, S. (2001). L'intimité surexposée. Paris: Éditions Ramsay.

Tisseron, S. (2007). Le virtuel à l'adolescence: autodestruction ou autothérapie? Neuropsychiatrie de l'enfance et de l'adolescence, 55(5-6), 264-268.

Vinocur Fischbein, S. (2010). Psychoanalysis and Virtual Reality. The International Journal of Psychoanalysis, 91(4), 985-988. doi:10.1111/j.1745-8315.2010.00300.x

\section{Resumos}

(O adolescente e Facebook : Narciso sem eco )

Depois de nos termos questionado sobre o sucesso do dispositivo que é o Facebook em conjunto com os adolescentes, interrogamo-nos sobre os diferentes tipos de supereu e a sua articulação, em particular neste periodo de reajustes psíquicos. Pela predominância de lógicas orais e anais, Faebook convoca o adolescente ao terreno da regressão e pode conduzir a uma deserotização, e até mesmo a uma dessexualização do supereu edípico em favor do supereu cultural e do supereu arcaico, até uma lógica de evitação do sexual diante de tantas ameaças de dimensões estruturantes que são as categorias da falta e do desejo.

Palavras-chave: Facebook, supereu cultural, dispositivo, deserotização, adolescência

(L'adolescent et Facebook: Narcisse sans écho)

Après avoir analysé le succès que connaît le dispositif Facebook auprès des adolescents, nous nous nous interrogeons sur les différents types de surmoi et leur articulation, en particulier lors de cette période de remaniements psychiques. Par la prédominance de logiques orales et anales, Facebook convoque l'adolescent sur le terrain de la régression et peut conduire à la désérotisation, voire à la désexualisation du Surmoi odipien au profit du surmoi culturel et du surmoi archaïque, et peut éventuellement aboutir à la logique d'évitement du sexuel, étant donné la quantité de 


\section{ARTIGO}

menaces qui contiennent des dimensions structurantes, soit les catégories du manque et du désir.

Mots clés: Facebook, surmoi culturel, dispositif, désérotisation, adolescence

(El adolescente y Facebook: Narciso sin eco)

Después de habernos preguntado sobre el éxito del dispositivo conocido como Facebook entre los adolescentes, nos interrogamos sobre los diferentes tipos de superyó y sobre sus modos de articulación, particularmente, en este periodo de reajustes psíquicos. Por el predominio de lógicas orales y anales, Facebook conduce al adolescente al terreno de la regresión y puede llevar a una deserotización, o incluso a una desexualización del superyó edípico en favor del superyó cultural y del superyó arcaico, lo que puede conducir a una lógica que evite lo sexual ante tantas amenazas de dimensiones estructurales que son las categorías de la carencia y del deseo.

Palabras claves: Facebook, superyó cultural, dispositivo, deserotisacion adolescencia

(Der Adoleszent und Facebook: Narziss ohne Echo)

Nach unserer Untersuchung über Facebooks Erfolg bei Jugendlichen, analysieren wir die verschiedenen Arten des Über-Ichs und seine Artikulation, speziell in Bezug auf diese Periode der psychischen Reorganisation. Durch die Prädominanz der analen und oralen Logik setzt Facebook den Jugendlichen auf eine regressive Ebene, was zu einer Enterotisierung oder sogar zu einer Entsexualisierung des ödipalen Über-Ichs führen kann. Dies begünstigt das kulturelle und archaische Über-Ich und kann sogar zu einer Logik der Vermeidung des Sexuellen führen, angesichts der unzähligen Bedrohungen die strukturierende Dimensionen enthalten, d.h. die Kategorien des Mangels und des Wunsches.

Schlüsselwörter: Facebook, kulturelles Über-Ich, Dispositiv, Enterotisierung, Adoleszenz

\section{摘要}

脸书可以彰显出「超我」的各种不同面貌。因为脸书上盛行的逻辑是口腔 性与肛门性的, 青少年在此会往退行的方向发展, 情欲化的途径因此受阻, 甚 至导致从伊底帕斯衍生而来的超我之「去性化」。相反的, 文化性的超我以及 古老的、非性的超我趁势而起，最终导致对性、性特质的全然回避。「少了什 么」或是「对某事某物存有着欲望」当中所具有的结构性的力量, 也因此将受 到威胁。

关键字：脸书，文化性的超我，装置，去性化，青少年 
Citação/Citation: Petit, L., Boisseuil, An., Iffli, S. (2015, dezembro). Adolescents and Facebook: Narcissus without (an) Echo. Revista Latinoamericana de Psicopatologia Fundamental, 18(4), 663-678.

Editoras do artigo/Editors: Prof. Dr. Manoel Tosta Belinck e Profa. Sonia Leite

Recebido/Received: 30.11.2014/ 11.30.2014 Aceito/Accepted: 20.1.2015 / 1.20.2015

Copyright: C 2009 Associação Universitária de Pesquisa em Psicopatologia Fundamental/ University Association for Research in Fundamental Psychopathology. Este é um artigo de livre acesso, que permite uso irrestrito, distribuição e reprodução em qualquer meio, desde que o autor e a fonte sejam citados / This is an open-access article, which permits unrestricted use, distribution, and reproduction in any medium, provided the original authors and sources are credited.

Financiamento/Funding: As autoras declaram não terem sido financiadas ou apoiadas / The authors have no support or funding to report.

Conflito de interesses/Conflict of interest: As autoras declaram que não há conflito de interesses / The authors have no conflict of interest to declare.

\section{Laetitia Petit}

Maître de conférences en psychologie clinique. Département de psychologie clinique; Membre du Laboratoire psychologie clinique et psychopathologie: langage et subjectivité. Pôle Psychologie, Sciences de 1'Education

Aix-Marseille Université

2 rue de la Loge

13002 Marseille, France

e-mail: maria-laetitia.petit@univ-amu.fr

\section{Anne Boisseuil}

Research assistant, University of Lyon 2, Aix-Marseille University.

24, Bd Grassendi

13012 Marseille, France

e-mail: aboisseuil@gmail.com

\section{SANDIE IfFLI}

Laboratory of Clinical Psychology and Psychopathology: Langage et Subjectivity, Aix-Marseille University.

La Closerie des Platanes Bat C

2 rue Georges Reboul

84000 Avignon, France

e-mail: sandie.iff@gmail.com

\section{(cc) BY-NC}

This is an open-access article, which permits unrestricted use, distribution, and reproduction in any medium for non-commercial purposes provided the original authors and sources are credited. 